W bardzo interesującej i intensywnej części dyskusyjnej podjęto przede wszystkim trudny temat udziału uniwersyteckich prawników w tworzeniu ideologii i działalności aparatu władzy państwa totalitarnego, w tym zwłaszcza zaangażowania niemieckich uczonych - jak chociażby Hansa Helfritza - w doktrynę i praktykę nazizmu. Wspominano także osiagnięcia innych znakomitych prawników, którym nie poświęcono całych wystapień, a więc między innymi Theodora Mommsena, Karla Augusta Unterholznera, Kamila Stefki, Tadeusza Bigo, Andrzeja Mycielskiego, Seweryna Wysłoucha, Franciszka Longchamps de Berier, Franciszka Ryszki, Waleriana Pańki i Jana Kosika. Wszystkie omawiane podczas dyskusji kwestie znajdą się zapewne, wraz z tekstami referatów, w publikacji, która już niebawem będzie efektem konferencji.

PIOTR SZYMANIEC (Wroclaw)

\title{
MIĘDZYNARODOWA KONFERENCJA NAUKOWA DLA UCZCZENIA JUBILEUSZU ABGB W PRADZE
}

W dniach 22-23 listopada 2011 r. na Wydziale Prawa Uniwersytetu Karola w Pradze odbyła się międzynarodowa konferencja naukowa z okazji 200-lecia austriackiego kodeksu cywilnego ABGB. Obrady, uroczyście otwarte z udziałem władz Wydziału Prawa Uniwersytetu Karola oraz zaproszonych gości, między innymi władz korporacji prawniczych, prowadzone były równolegle w dwóch sekcjach: historycznoprawnej oraz cywilistycznej.

Obradom sekcji historycznoprawnej przewodniczyl wybitny czeski historyk prawa, prof. Karel Maly, wieloletni prorektor i rektor Uniwersytetu Karola w Pradze. Wśród zagranicznych gości, którzy wzięli udział w tej części konferencji znaleźli się między innymi prof. Werner Ogris z Uniwersytetu Wiedeńskiego, prof. Monika Niedermayr z Innsbrucku, prof. Gerhard Lingelbach z Friedrich-Schiller Uniwersität, a także pisząca te słowa prof. Dorota Malec z Uniwersytetu Jagiellońskiego. Wśród referentów najliczniej reprezentowani byli uczeni z ośrodka praskiego, ale także Bratysławy, Brna i Olomuńca.

Program zaledwie dwudniowej konferencji obejmował 29 referatów, poświęconych wybranym zagadnieniom dziejów prawa cywilnego, spośród których na pierwszym planie znalazły się problemy wpływu ABGB na prace kodyfikacyjne w okresie międzywojennym i pierwszych latach po II wojnie światowej, podejmowane w szerokim, nie tylko śrokowoeuropejskim zakresie.

Konferencję otworzył interesujący, oparty na bogatych archiwalnych podstawach źródłowych referat prof. Moniki Niedermayr z Innsbrucku, poświęcony orzecznictwu Sądu Najwyższego i praktyce sądowej z okresu wprowadzania ABGB w życie. Prof. Gerhard Lingelbach z Jeny skoncentrował swe wystapienie wokół problematyki wpływu ABGB na saksoński kodeks cywilny z roku 1863/1865, i pośrednio, poprzez ów kodeks, na niemiecką kodyfikację BGB. W syntetycznym referacie prof. Radima Seltenreicha przedstawione zostały starania kodyfikacyjne na terytoriach niemieckich w XVIII i XIX w.

Kolejni referenci skoncentrowali swe wystapienia na problematyce XX-wiecznej, począwszy od prac nad nowelizacją ABGB w latach I wojny światowej, z interesującym wątkiem polskim - udziałem w nich krakowskiego cywilisty, a zarazem galicyjskiego polityka Stanisława Madeyskiego (Ladislav Soukup). Ogólne zagadnienia kodyfikacji prawa i wpływu między innymi $\mathrm{ABGB}$ na działania kodyfikacyjne w krajach europejskich w okresie międzywojennym zaakcentowane zostały w referatach Jana Kuklika, Petry Skṙejpkovej oraz Doroty Malec. Podjęto także wątek ustawodawstwa w zakresie prawa cywilnego dla terenów słowackich w latach 1938-1945 (Ondřej Podolec), relacji między przepisami ABGB a Konstytucją Czechosłowacji 
z 1948 r. (Vladimir Kindl) oraz elementom konstytucyjnym w ABGB (Karolina Adamova), zagadnieniom przynależności państwowej jako przedmiotowi zainteresowania ABGB (Marek Stary), rzymskich korzeni kontraktów realnych w ABGB (Michal Skrejpek) i recepcji rzymskiego systemu kontraktów (Jiri L. Bíly), pojęciu własności (Ondrej Horak), posiadania i dobrej wiary w prawie rzymskim i współczesnym czeskim prawie cywilnym (Petr Dostalik), historycznym korzeniom i współczesnym regulacjom kary umownej.

Zaprezentowano także wystappienia poświęcone problematyce umów o pracę w ABGB i prawie przemysłowym (Ladislav Vojaček), analizie pojęcia osobowości prawnej w pierwszej połowie XIX w. (Karel Beran), prawnonaturalnym aspektom ABGB (Pavel Maršalek), wpływom prawa kanonicznego na rozwiązania w zakresie prawa małżeńskiego w ABGB (Jiři Tretera, Záboj Horák), stosunkom majątkowym małżeńskim (Ivana Starä), prawnej ochronie sierot (Pavla Slavičkova), położeniu ludności żydowskiej w świetle przepisów ABGB (René Petraš) oraz prawu spadkowemu (Karel Schelle).

Większość referentów, wśród których dominowali czescy uczeni, akcentowała w swych wystapieniach znaczenie ABGB i jego wpływ na rozwój prawa na terenach czeskich i słowackich. Jak wyżej wspomniano, interesująco zaprezentowano wystapienia dotyczące prób kodyfikacji prawa, podejmowanych w podobnym jak w Polsce okresie. Warto podkreślić, że nawet $w$ wystąpieniach poświęconych szczegółowym kwestiom prawnym odnaleźć można było bardzo ciekawe wątki polskie. W szczególności zwracały uwagę rozważania na temat problemów z powstawaniem czeskiego języka prawnego, widoczne $\mathrm{w}$ pierwszych thumaczeniach kodeksu ABGB na język czeski, podczas których podpierano się, a niekiedy wprost używano terminologii polskiej, jak w wypadku kłopotów z thumaczeniem pojęcia ,eigentum”, gdy sięgnięto wprost po polski termin „własność”. Do polskiej terminologii sięgano także w okresie po II wojnie światowej. Ten niezwykle interesujący wątek zasługuje na uwage także nauki polskiej, która zagadnieniom tworzenia się nowoczesnej polskiej terminologii prawniczej nie poświęcała dotychczas zbyt wiele uwagi. Na marginesie warto w tym miejscu przypomnieć postać niemal zapomnianego prawnika z Galicji, Michała Stojowskiego, którego tłumaczenie ABGB z 1811 r. miało w tym zakresie duże znaczenie.

Konferencja była ostatnim spotkaniem po cyklu jubileuszowych konferencji odbywajacych się między innymi w Wiedniu, Krakowie, Frankfurcie nad Menem, poświęconym jubileuszowi austriackiej kodyfikacji. Organizatorzy, którym udało się stworzyć podczas obrad bardzo życzliwą, a zarazem skłaniającą do naukowej dyskusji atmosferę, przygotowują publikację wszystkich wygłoszonych podczas spotkania referatów.

DOROTA MALEC (Kraków)

\section{SYMPOZJUM HISTORYKÓW PAŃSTWA I PRAWA POLSKIEGO W KRAKOWIE (16 stycznia 2012)}

Na Zjeździe Katedr Historyczno-Prawnych w Zegrzu w 2010 r. prof. Wacław Uruszczak przedstawił propozycję odbywania odrębnych konferencji historyków prawa polskiego. Taki był początek inicjatywy, która zaowocowała zorganizowaniem przez Katedrę Historii Prawa Polskiego oraz Katedrę Historii Administracji i Myśli Administracyjnej UJ w dniu 16 stycznia 2012 r. I Sympozjum Historyków Państwa i Prawa Polskiego w Krakowie. Organizatorzy sympozjum początkowo planowali jego odbycie jesienią 2011 r., a zatem w połowie dwulecia dzielącego Zjazdy Katedr Historyczno-Prawnych, jednak z powodu trudności technicznych (wiążących się z zaangażowaniem Uniwersytetu w trakcie polskiej prezydencji w Unii Europejskiej) spotkanie to zostało przeniesione na początek obecnego roku kalendarzowego. Idea, 